in a nesting colony near Fort Qu'Appelle (E. M. Callin) indicate a northward extension of the range of these two species. Current observations supplement historical records in showing that the Magpie population has its ups and downs. Similarly, the Lark Bunting (abundant, for example, at Hawarden in 1950 for the first time since 1937) and the Bobolink (for example, rarely seen now at Sheho where once common) illustrate fluctuating bird populations.

One of the most valuable lists published by the Blue Jay (Vol. 1, No. 3) is Laurence B. Potter's Saskatchewan Bird Records made since the publication of Mitchell's Catalogue of Saskatchewan Birds in 1924. There have also appeared reviews of local lists that begin to supply a regional picture of bird life in the province; namely Stuart Houston's Birds of the Yorkton District, Maurice Street's List of the Birds of Nipawin, Saskatchewan, and the Hoopers' Preliminary List of the Birds of the Somme District. Contributions like the ones mentioned in this report have won the Blue Jay congratulations from such famous ornithologists as J. J. Hickey, author of A Guide to Bird Watching, and P. A. Taverner, well-known author of Birds of Canada.

\section{Recollections of a Night's Rest by the Slough}

By J. H. Grant, Harlan, Sask.

All the long, hot day we travelled in the teeth of a chinook that sent Tumble Weeds bounding over the searing plain and whipped grass tops and weed seeds into our blistering faces - and at evening, arrived at a tiny lake on the edge of the scrubland.

The red sun sank behind a hill and down with it went the wind. Air, cool, soothing and laden with the smell of water crept out from the slough which mirrored dark-green clumps of choke-cherry bush and one patch of crimson sky. A pair of muskrats swam leisurely, leaving in their wake twin "v's" of tiny ripples. A Robin sang from a Silver-berry bush, his inimitable liquid notes mingling with the murmur of the streamlet that fed the pond. From her nest on a Cottonwood stump, a Mourning Dove crooned her plaintive lay, and from somewhere in the range lands beyond, faint and far away came the lowing of cattle.

As dusk settled, the oxen, fullfed on the lush grasses of the lake shore, lay down by the wagon, drawing deep contented breaths and ruminating peacefully. We lay on the warm sand; the fresh vapor-laden air balm to our wind-chafed lips and nostrils, and the mellow gurgling call of the Bittern lulling us to rest.

\section{STOP! Don't Shoot That Bird!}

\section{By Donald Hooper, Somme, Sask.}

Too often a hawk or owl lands in a tree near a farmyard, and the farmer rushes out with a gun and shoots the bird, not stopping to see if it is a friend or foe. We must remember that, as well as poultry in the yard, there are often many rats and mice around the barn, feed corrals and sheaf stacks.

In the winter time the Prairie and Varying Hare feed around the barnyards at night attracting Great Horned Owls. These owls are generally shot by the farmers. It would be much better to shoot near the bird and scare it away if it seems that the chickens are in danger.

This spring, a Great Horned Owl came to our yard and perched on the barn to watch for hares and rats. This bird must have had young ones to feed, for he came day and night for about a week. Sometimes during the day he would sit in the straw near the ruins of an old log barn. There the owl would watch by the hour for rats. The hen house was nearby and the yard was full of poultry but the owl didn't pay any attention to them.

I think that the Great Horned Owl should be protected more. In our district they are becoming scarcer because so many are shot and nests are destroyed. 